RASĀYAN J. Chem.

Vol. 13 | No. 3 |1719-1726| July - September | 2020 ISSN: 0974-1496 | e-ISSN: 0976-0083 | CODEN: RJCABP

\title{
THE APPLICATION OF PROBIOTIC DRYING WITH SIMPLE METHODS AND EFFECT ON BLOOD CHOLESTEROL LEVELS CHICKEN BROILER
}

\author{
C. Kumalasari ${ }^{1}$, Muchtaridi Muchtaridi ${ }^{3}$,*, I. Setiawan ${ }^{2}$ and L. Adriani ${ }^{1}$ \\ ${ }^{1}$ Department of Animal Nutrition and Feed Technology, Faculty of Animal Husbandry, \\ Universitas Padjadjaran, 45363, Indonesia \\ ${ }^{2}$ Department of Animal Production, Faculty of Animal Husbandry, Universitas Padjadjaran, \\ 45363, Indonesia \\ ${ }^{3}$ Department of Pharmaceutical Analysis and Medicinal Chemistry, Faculty of Pharmacy, \\ Universitas Padjadjaran, 45363, Indonesia \\ *E-mail: muchtaridi@unpad.ac.id
}

\begin{abstract}
Probiotic is indicated will improve and maintain the balance of microorganisms in the digestive tract when it is consumed. This study aimed to know the influence of dried probiotic against the blood cholesterol level of the chicken broiler. Dried probiotics consist of four types of formulations; there are (A) $100 \%$ fermented cow's milk, (B) combination of $75 \%$ fermented cow's milk and $25 \%$ fermented mung bean milk, (C) combination of $75 \%$ fermented cow's milk and $25 \%$ fermented soybean milk, and (D) combination of $50 \%$ fermented cow's milk, $25 \%$ fermented mung bean milk, and $25 \%$ fermented soybean milk. Oven-dry method finished by using a $40^{\circ} \mathrm{C}$ for 25 hours, until the water content to $10 \%$. The advantages of oven-dry are easy to operate and microorganisms still alive. The quality of dried probiotics can be seen from the $\mathrm{pH}$, lactic acid levels, total lactic acid bacteria, and total bacteria. The results showed that $\mathrm{pH}$ ranges from 3.78 to 4.03 and lactic acid levels 0.64 to $0.74 \%$. Each total of lactic acid bacteria is (A) $4.51 \times 10^{3} \mathrm{CFU} / \mathrm{g}$, (B) $3.49 \times 10^{3} \mathrm{CFU} / \mathrm{g}$, (C) $3.85 \times 10^{3} \mathrm{CFU} / \mathrm{g}$, (D) $7.09 \times 10^{2} \mathrm{CFU} / \mathrm{g}$. Meanwhile, each total bacterium (A) $1.27 \times 10^{3} \mathrm{CFU} / \mathrm{g}$, (B) $6.10 \times 10^{6} \mathrm{CFU} / \mathrm{g}$, (C) $1.70 \times 10^{3} \mathrm{CFU} / \mathrm{g}$, and (D) $1.28 \times 10^{3} \mathrm{CFU} / \mathrm{g}$. The study showed that dried probiotics administration effective to reduce broiler blood cholesterol levels, even though probiotic quality decreased especially the total lactic acid bacteria and total bacteria.
\end{abstract}

Keywords: Dried Probiotic, Physical Quality, Biological Quality, Blood Cholesterol Levels, Broiler Chicken.

(C) RASĀYAN. All rights reserved

\section{INTRODUCTION}

Probiotics are living microorganisms that provide health benefits if consumed in sufficient quantities. ${ }^{1}$ Probiotics are known as alternative antibiotics that can reduce oxidative stress, improve intestinal health, and improve livestock performance. Moreover, the benefits of consuming probiotics can produce enzymes that are also assisting digestion and antibacterial substances to suppress harmful microorganisms. Besides that, the immune system and metabolism produce important nutrients such as vitamin $\mathrm{B}$ and vitamin $\mathrm{K}$ as antioxidant precursors. ${ }^{2}$ Dried probiotics contain Lactic Acid Bacteria (LAB) including Lactobacillus bulgaricus, Lactobacillus acidophilus, Streptococcus thermophilus, and Bifidobacterium bifidum.

LAB is contained in fermented milk based on cow milk, mung bean milk, and soybean milk. According to Adriani ${ }^{3}$, Lactobacillus bulgaricus and Streptococcus thermophilus are not included as a reliable probiotic, because these two bacteria are reduced in the colon. Both of these bacteria are mesophilic bacteria that can survive at a temperature tolerance of $35-45^{\circ} \mathrm{C}$. Lactobacillus acidophilus has lived along the digestive tract and obtained in very large amounts of the small intestine. Lactobacillus acidophilus is a bacterium that can stick to the epithelial cells of the digestive tract. The temperature tolerance of these bacteria is around 35$38^{\circ} \mathrm{C} .{ }^{4}$ Lactobacillus acidophilus and Bifidobacterium spp. have better resistance to the human digestive

Rasayan J. Chem., 13(3), 1719-1726(2020)

http://dx.doi.org/10.31788/RJC.2020.1335764

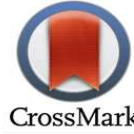


RASĀYAN J. Chem.

Vol. 13 | No. 3 |1719-1726| July - September | 2020

tract. In addition to LAB, the isoflavone content of soybeans and mung bean shows a decrease in cholesterol levels in the blood chicken broiler. Moreover, isoflavone is known as a secondary metabolite produced by plants, which can be used to prevent cell damage caused by free radicals. ${ }^{5}$ Furthermore, the functions of isoflavone include estrogen, hypocholesterolemia, improve digestive tract function, prevent breast, prostate and colon cancer, improve bone health, and lipid metabolism. ${ }^{6}$

Probiotics are widely used in the liquid form. Nowadays, dried probiotic is used widely because it is easy to be applied. Probiotic is one of the products that are sensitive to heat, so a proper method needs to be applied to produce dried probiotic. ${ }^{7}$

Drying is one of the easiest methods that used to extend shelf life. The basic principle of drying is to reduce water content. Some common methods used in drying techniques are freezing, oven drying, vacuum oven, spray drying, drying with fluid flow, freeze-drying, and lyophilization. ${ }^{8}$ Therefore, each of the methods has its advantages and disadvantages.

One of drying technique that is easily applied to a low-cost is oven drying. Although the result of oven drying is not good enough due to a decrease in the number of microorganism cells, the benefits of probiotics are still ideal because there is an isoflavone content. Dried probiotics are obtained from fermented cow's milk, soy milk, and mung bean milk.

Research towards liquid probiotic with a combination of cow's milk and fermented soy milk has been conducted by some experts. However, the use of dry probiotics with this combination is still not widely applied. Therefore, this research is aimed to find out the quality of dried probiotics and their effect on blood cholesterol. During the fermentation process of soybeans and mung beans are needed to add cow's milk, because beans have low lactose content. Fermented bean at $\mathrm{pH} 5$ can hydrolyze isoflavone in the form of glucoside into aglycones by the enzyme $\beta$-glucosidase by releasing their glycosidic bonds. ${ }^{9}$ Isoflavone in the form of aglycones is more easily absorbed by the small intestine as part of the micelles formed by bile. Mung beans (Vigna radiata, L.) contain $345 \mathrm{kcals}$ of energy, $22 \mathrm{~g}$ of protein, $1.2 \mathrm{~g}$ of fat, $62.9 \mathrm{~g}$ of carbohydrate, $125 \mathrm{mg}$ of calcium, $320 \mathrm{mg}$ of phosphorus, $6.7 \mathrm{mg}$ of iron, $157 \mathrm{SI}$ of vitamin A, $0.64 \mathrm{mg}$ of vitamin B2, $6 \mathrm{mg}$ of vitamin $\mathrm{C}$, and $10 \mathrm{~g}$ of water in every 100 grams of seeds. ${ }^{10}$ The benefits of consuming mung beans can reduce cholesterol levels, antioxidant, and antimicrobial function. ${ }^{1}$ These benefits are influenced by a flavonoid, phenolic acid, protein, amino acid, lipid, mineral, and other metabolites. ${ }^{11}$ Furthermore, the nutritional composition of soybeans per $100 \mathrm{~g}$ of seeds included $3.7 \mathrm{~g}$ protein, $2.8 \mathrm{~g}$ carbohydrates, $0.6 \mathrm{~g}$ fiber, $120 \mathrm{mg}$ calcium, $0.2 \mathrm{mg}$ vitamin $\mathrm{B} 12$, and $2.2 \mathrm{~g}$ total fat. There are also 0.4 saturated fatty acids, $0.5 \mathrm{~g}$ monounsaturated fatty acids, $1.3 \mathrm{~g}$ polyunsaturated fatty acids consisting of linolenic acid (omega 6), $1.2 \mathrm{~g}$ and alpha-linolenic acid (omega 3) $0.2 \mathrm{~g} .{ }^{12}$

In this study, dried probiotics were conducted for 4 formulations including, (A) $100 \%$ fermented cow's milk, (B) combination of 75\% fermented cow's milk and $25 \%$ fermented mung bean milk, (C) combination of $75 \%$ fermented cow's milk and $25 \%$ fermented soybean milk, and (D) combination of $50 \%$ fermented cow's milk, $25 \%$ fermented mung bean milk, and 25\% fermented soybean milk. Drying was applied by using a dry oven for 25 hours of $40^{\circ} \mathrm{C}$. Probiotic bacteria are coated with maltodextrin DE 10-12 (food grade) $5 \%$ as a nutrient to keep bacteria still alive.

In vivo testing, dried probiotics were applied to broilers against blood cholesterol. Blood cholesterol and triglyceride levels can be decreased by dried probiotic. ${ }^{13}$ The dried probiotics administrated to broilers for a dose of $2 \%$ of total rations. In this study, examined the quality of physical and biological dried probiotics. Physical quality to the degree of acidity $(\mathrm{pH})$ and lactic acid levels, while the biological quality of the total lactic acid bacteria and total bacteria.

This research is important for knowing dried probiotic with combination cow's milk, soybean milk, and mung bean milk fermented that have resulted to decrease cholesterol blood level chicken broiler.

\section{Materials}

\section{EXPERIMENTAL}

Cow's milk (KPSBU, Lembang), soybean and mung bean (Kurnia, Bandung), starters Lactobacillus bulgaricus, Lactobacillus acidophilus, Streptococcus thermophilus, Bifidobacterium bifidum (Yogourmet, Canada), maltodextrin DE 10-12 (Subur Kimia Jaya, Bandung), CHOD-PAP or Cholesterol Oxidase Phenylperoxidase Amino Phenozonphenol (Biolabo, Bandung). 
RASĀYAN J. Chem.

Vol. 13 | No. 3 |1719-1726| July - September | 2020

\section{Processing of Dried Probiotic}

Cow's milk, soybean milk, and mung bean milk were fermented with four microbes there are Lactobacillus bulgaricus, Lactobacillus acidophilus, Streptococcus thermophilus, and Bifidobacterium bifidum. Fermented milks were coated with maltodextrin $5 \%$ as a nutrient for microorganisms to stay alive. Drying probiotic used the dry oven with a temperature of $40^{\circ} \mathrm{C}$ for 25 hours from the liquid phase to solids. This oven drying method was equipped with a thermostat, thermometer, and blower. Microbial mixtures include Lactobacillus bulgaricuss: Lactobacillus acidophilus : Streptococcus thermophilus : Bifidobacterium bifidum $=1: 1: 1: 1$. The dried probiotics administrated to broilers for a dose of $2 \%$ of total rations.

\section{Bird and Ration}

A total of 100 day-old broiler chicks (taken from CV Missouri, Bandung) without sex separation with a standard deviation of body weight, not more than 10 percent were used in the experiment. Cages were used 20 units of experimental cages. Each cage measures $1 \times 0.5 \times 0.75 \mathrm{~m}$ which was equipped with a feed and drinking water. The experiment was conducted for 28 days. The provision of rations was carried out twice a day in the morning and evening, while the provision of drinking water was carried out ad-libitum. Dried probiotics $(2 \%)$ were put into rations. Completely Randomized Design was used in this experiment with 5 treatments and 4 replications. The treatments consisted of T- $1=$ basal diet without dried probiotic ; $\mathrm{T}-2=$ basal diet $+2 \%$ dried probiotic A ( $100 \%$ fermented cow's milk); T-3 = basal diet $+2 \%$ dried probiotic B (a combination of $75 \%$ fermented cow's milk and $25 \%$ fermented mung bean milk); T- $4=$ basal diet $+2 \%$ dried probiotic C (a combination of 75\% fermented cow's milk and $25 \%$ fermented soybean milk); T-5 = basal diet $+2 \%$ dried probiotic $\mathrm{D}$ (a combination of $50 \%$ fermented cow's milk, $25 \%$ fermented mung bean milk, and $25 \%$ fermented soybean milk).

\section{Detection Method}

Twenty blood samples collected per replication, randomly. The samples were analyzed at the Laboratory of Physiology and Biochemistry, Faculty of Animal Husbandry, University of Padjadjaran. The parameters recorded were cholesterol blood level. Analyze was used Cholesterol Oxidase Phenylperoxidase Amino Phenozonphenol (CHOD-PAP).

\section{Statistical Analysis}

Measured data were analyzed using the one-way analysis of variance (ANOVA). The significant differences among treatments were investigated using Duncan's Test at $\mathrm{P}<0.05$.

\section{RESULTS AND DISCUSSION \\ The Effect of Oven-Dry Method on Dried Probiotics Physical Quality}

The $\mathrm{pH}$ of the four dried probiotic products ranges from 3.78 to 4.03 . There are 3.97 (dried probiotic A), 3.97 (dried probiotic B), 3.78 (dried probiotic C), and 4.03 (dried probiotic D) produce the usual $\mathrm{pH}$ in fermented products in a liquid state. The degree of acidity $(\mathrm{pH})$ that should be achieved by yogurt is 4.5 . Dried probiotics lactic acid levels A, B, C, and D respectively $0.68 \%, 0.64 \%, 0.74 \%$, and 0.73 . The results of the data are following the lactic acid content required by SNI $2981-2009$, which is between $0.5 \%-2.0 \%$. The decreased $\mathrm{pH}$ in dried probiotics is influenced by the presence of LAB activity in change lactose into lactic acid as glucose metabolism. The catabolism of lactose into lactic acid by homofermentative bacteria occurs through the process of glycolysis (the Embden-Meyerhoff-Parnass pathway), which converts lactose to pyruvic acid, then change into lactic acid. ${ }^{14}$

LAB contained in these probiotics synergizes each other in cell multiplication. Streptococcus thermophilus is produced pyruvic acid, formic acid, and $\mathrm{CO}_{2}$, as well as folic acid which stimulates the growth of Lactobacillus bulgaricus. Lactobacillus bulgaricus will secretion the amino acids valine, glycine and histidine needed by Streptococcus thermophilus. While the bacteria Lactobacillus acidophilus and Bifidobacterium spp. grow slowly during the process of making yogurt. ${ }^{15}$

Streptococci type bacteria are responsible for the decrease in the initial $\mathrm{pH}$ of yogurt to around 5,0. Then the Lactobacilli species is responsible for further decreases until the $\mathrm{pH}$ reaches 4.5. Probiotic bacteria especially Lactobacillus acidophilus when combined with Streptococcus thermophilus and Lactobacillus 
RASĀYAN J. Chem.

Vol. 13 | No. 3 |1719-1726| July - September | 2020

bulgaricus bacteria can produce yogurt with a lower $\mathrm{pH}$ because it can ferment sugar into lactic acid quickly.

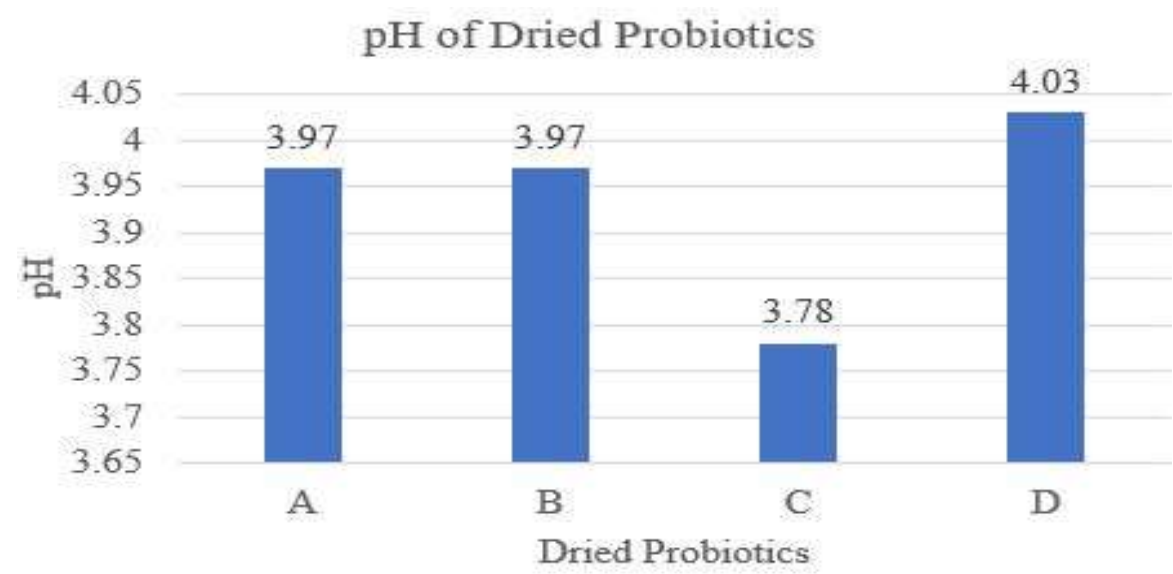

Fig.-1: pH of Dried Probiotics

\section{Lactic Acid Levels of Dried Probiotics}

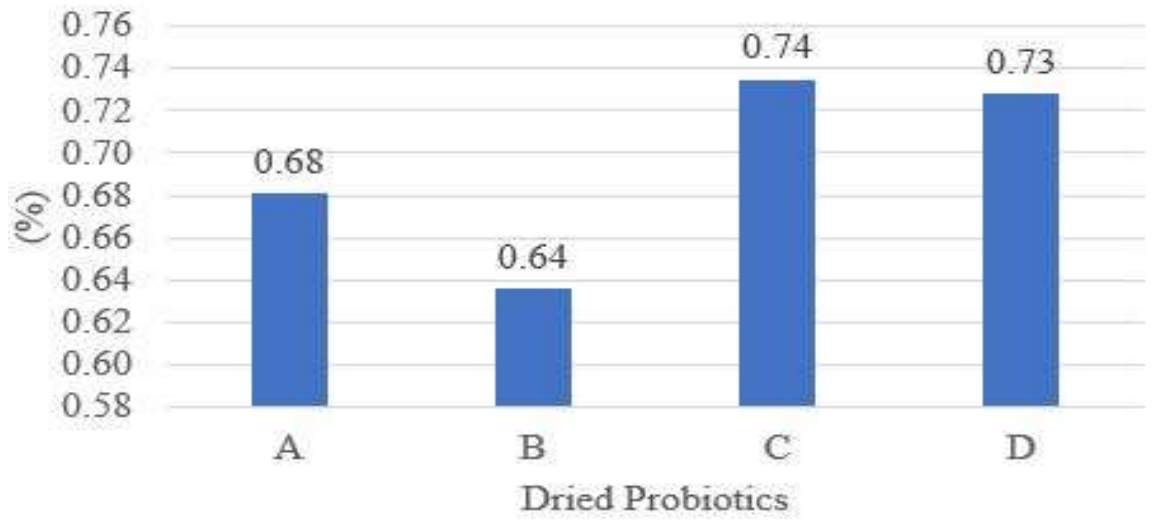

Fig.-2: Lactic Acid Level of Dried Probiotic

Lactobacillus achidophilus bacteria yogurt can increase acidity quickly and produce $\mathrm{pH}$ values below 4 . An increase in lactic acid levels in fermented milk is always balanced with a decrease in $\mathrm{pH}$ of yogurt, meaning that the greater the level of lactic acid formed during fermentation, the $\mathrm{pH}$ of yogurt decreases, but the decrease in lactose content is not always balanced with an increase in lactic acid levels. ${ }^{16}$

Probiotics coated with 5\% maltodextrin using the freeze-dry drying method produced lactic acid levels of $1.24 \%$ and $\mathrm{pH} 3.7$; lactic acid levels $0.69 \%$; and lactic acid levels $0.77 \%$ and $\mathrm{pH} 4.09 .{ }^{17,18,7}$ Spray drying method produces lactic acid levels of 1.03 to $1.48 \%$ and a $\mathrm{pH}$ value of 3.91 to $4.41 .{ }^{19}$ Physical quality by measuring $\mathrm{pH}$ and lactic acid levels in dry probiotics obtain results following SNI 2009. Other than, that it is in the same range as other drying methods.

\section{The Effect of Oven-Dry Method on Probiotics Dried Biological Quality}

The total of lactic acid bacteria has decreased after drying with the oven. The total of lactic acid bacteria ranges from $10^{2}$ to $10^{3} \mathrm{CFU} / \mathrm{g}$. The total lactic acid bacteria of dried probiotics $\mathrm{A}, \mathrm{B}, \mathrm{C}$, and $\mathrm{D}$ respectively $4.51 \times 10^{3} \mathrm{CFU} / \mathrm{g}, 3.49 \times 10^{3} \mathrm{CFU} / \mathrm{g}, 3.85 \times 10^{3} \mathrm{CFU} / \mathrm{g}$, and $7.09 \times 10^{2} \mathrm{CFU} / \mathrm{g}$. The total bacteria ranged from $10^{3}$ to $10^{6} \mathrm{CFU} / \mathrm{g}$. The total bacteria of dried probiotics A, B, C, and D respectively $1.27 \times 10^{3} \mathrm{CFU} / \mathrm{g}$, $6.10 \times 10^{6} \mathrm{CFU} / \mathrm{g}, 1.70 \times 10^{3} \mathrm{CFU} / \mathrm{g}$, and $1.28 \times 10^{3} \mathrm{CFU} / \mathrm{g}$.

The difference in total LAB of each dried probiotic formulation is influenced by the availability of carbohydrate substrate as a source of energy in the media, namely lactose. The total LAB in dried probiotic A with the highest formulation of fermented cow's milk $100 \%$ which is $4.51 \times 10^{3} \mathrm{CFU} / \mathrm{gr}$ because of high 
RASĀYAN J. Chem.

Vol. 13 | No. 3 |1719-1726| July - September | 2020

lactose content, so that the production of lactic acid is also high. The total LAB in dried probiotic D with formulation of $50 \%$ fermented cow's milk $+25 \%$ fermented mung bean milk $+25 \%$ fermented soybean milk is the lowest compared to other formulas, which is $7.09 \times 10^{2} \mathrm{CFU} / \mathrm{gr}$. This is because dried probiotic D only contains $50 \%$ cow's milk with a little lactose, so the production of lactic acid is low. Mung bean and soybean contain carbohydrates in oligosaccharides which cannot be directly utilized by LAB, whereas cow's milk contains lactose which can be used directly as an energy source by LAB. Therefore, in the fermentation process of mung bean milk and soybean must be mixed with cow's milk. Lactobacillus bulgaricus, Lactobacillus acidophilus and Streptococcus thermophilus can consume monosaccharides and disaccharides, but cannot consume oligosaccharides. ${ }^{20}$ Whereas Bifidobacterium bifidum can utilize oligosaccharides such as rafinosa and stakiosa found in soybeans. ${ }^{21}$

Table-1: Total Lactic Acid Bacteria and Total Bacteria on Dried Probiotics

\begin{tabular}{c|c|c|c|c}
\hline \multirow{2}{*}{ Variable } & \multicolumn{4}{|c}{ Probiotic (CFU/g) } \\
\cline { 2 - 5 } & $\mathrm{A}$ & $\mathrm{B}$ & $\mathrm{C}$ & $\mathrm{D}$ \\
\hline Total LAB & $4.51 \times 10^{3}$ & $3.49 \times 10^{3}$ & $3.85 \times 10^{3}$ & $7.09 \times 10^{2}$ \\
\hline Total Bacteria & $1.27 \times 10^{3}$ & $6.10 \times 10^{6}$ & $1.70 \times 10^{3}$ & $1.28 \times 10^{3}$ \\
\hline
\end{tabular}

The use of freeze-drying and spray drying methods results in higher bacterial viability compared to oven drying. Probiotics coated with 5\% maltodextrin using the freeze-drying method produced a total lactic acid bacteria $4.06 \times 10^{7}, 1.34 \times 10^{9}, 2.34 \times 10^{10} \mathrm{CFU} / \mathrm{g}{ }^{7,17,18}$. The spray-drying of sweet yogurt added with maltodextrin with an inlet temperature of $148^{\circ} \mathrm{C}$ produced the number of $S$. thermophilus bacteria between $0.8 \times 10^{-3}$ until $0.03 \times 10^{-1}$. Lactobacillus bulgaricus ranges from $0.64 \times 10^{-3}$ to $0.06 \times 10^{-1}$. ${ }^{22}$ Whereas the spray-drying method at the $60^{\circ} \mathrm{C}$ outlet air temperature produced the number of Streptococcus thermophilus and Lactobacillus delbrueckii subsp. bulgaricus were $1.84 \times 10^{7}$ and $4.39 \times 10^{6} \mathrm{CFU} / \mathrm{g}$ dry matter from fresh yogurt with levels of $10^{7}$ to $10^{8} .^{19}$ Ranadheera et al. ${ }^{23}$ using inlet temperature $195^{\circ} \mathrm{C}$ and outlet temperature of $85^{\circ} \mathrm{C}$ produces $>10^{7} \mathrm{CFU} / \mathrm{g}$ for Lactobacillus acidophilus LA-5 and $>10^{6} \mathrm{CFU} / \mathrm{g}$ for $B$. animalis subsp. lactis BB-12.

\section{The Effect of Dried Probiotics on Blood Cholesterol Levels Broiler Chickens}

The average blood cholesterol level on the 14th day was highest at T-1 at $163.34 \pm 5.41 \mathrm{mg} / \mathrm{dl}$ and the lowest at T-2, which was $138.27 \pm 9.18 \mathrm{mg} / \mathrm{dl}$. The blood cholesterol levels decreased compared to the treatment without the administration of dried probiotics, with the biggest decrease in T-2 at $15.35 \%$. Meanwhile, the average blood cholesterol levels on the 28th day were highest at T-3 was $158.86 \pm 9.79$ $\mathrm{mg} / \mathrm{dl}$ and the lowest at T-4 was $126.26 \pm 17.16 \mathrm{mg} / \mathrm{dl}$. The biggest decrease at T-4 was $19.48 \%$ compared to control. Statistical analysis showed that the results were not significantly different $(\mathrm{P}>0,05)$ to reduce blood cholesterol levels. Although not significantly different, the administration of dried probiotics shows a decrease.

Table-2: Blood Cholesterol Levels of Broiler Chickens

\begin{tabular}{c|c|c|c|c|c}
\hline \multirow{2}{*}{ Day } & \multicolumn{4}{|c|}{ Treatment } & \\
\cline { 2 - 6 } & T-1 & T-2 & T-3 & T-4 & T-5 \\
\hline 14th day & $163.34 \pm 5.41$ & $138.27 \pm 9.18$ & $144.91 \pm 4.81$ & $153.20 \pm 4.61$ & $158.91 \pm 8.42$ \\
\hline 28th day & $156.82 \pm 2.75$ & $158.64 \pm 11.45$ & $158.86 \pm 9.79$ & $126.26 \pm 17.16$ & $154.70 \pm 17.21$ \\
\hline
\end{tabular}

Note: $\quad \mathrm{T}-1=$ Basal diet

$\mathrm{T}-2=$ Basal diet $+2 \%$ dried probiotic A ( $100 \%$ fermented cow's milk)

$\mathrm{T}-3=$ Basal diet $+2 \%$ dried probiotic B (a combination of $75 \%$ fermented cow's milk and $25 \%$ fermented mung bean milk)

$\mathrm{T}-4=$ Basal diet $+2 \%$ dried probiotic $\mathrm{C}$ (a combination of $75 \%$ fermented cow's milk and $25 \%$ fermented soybean milk)

$\mathrm{T}-5=$ Basal diet $+2 \%$ dried probiotic D (a combination of $50 \%$ fermented cow's milk, $25 \%$ fermented mung bean milk, and $25 \%$ fermented soybean milk)

On the 14th day, the lowest blood cholesterol level showed by T-2 with the highest total LAB within all treatments. The mechanism to reduce endogenous cholesterol level can be done by deconjugating bile acids, 
RASĀYAN J. Chem.

cholesterol assimilation, and short-chain fatty acid production. While exogenous cholesterol can be reduced by decreasing cholesterol absorption in the small intestines due to cholesterol reductase enzyme activity. LAB produces the enzyme Bile Salt Hydrolase (BSH) or the C-24, N-acyl amide bond formed between bile acids and amino acids in the conjugation of bile salts. This enzyme produces deconjugated bile acid in free cholic acid form, which is less to absorbed than conjugated bile acid by the small intestines. Bile acids that are wasted through feces cause more cholesterol that is needed to synthesize bile salts again so that cholesterol levels eventually reduce. ${ }^{24}$ LAB play a role in conjugating bile salts in the intestine and preventing cholesterol synthesis. ${ }^{25}$

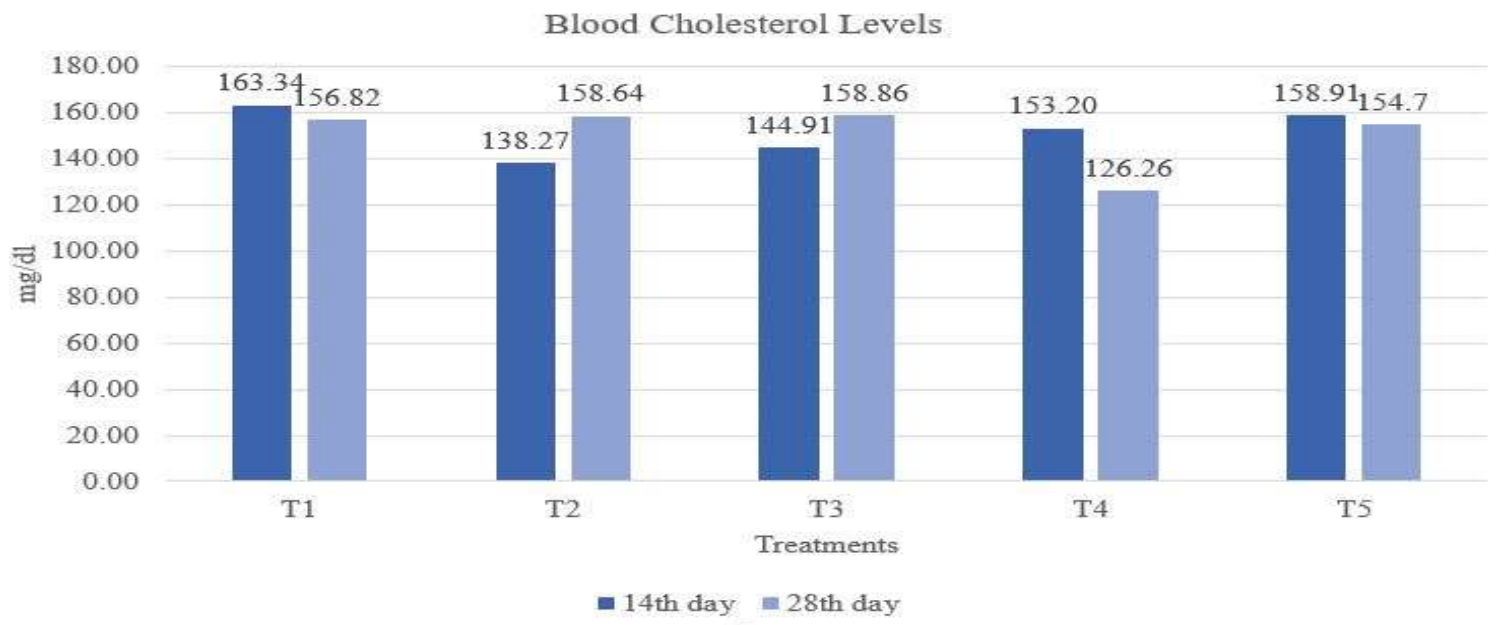

Fig.-3: The Average Blood Cholesterol Level of Broiler Chicken

LAB produce Short-Chain Fatty Acids (SCFA) such as butyric acid and propionic acid. This SCFA can affect cholesterol metabolism in the liver. Butyrate can inhibit liver cholesterol synthesis and provide a source of energy for intestines epithelial cells. Propionic acid was identified to decrease cholesterol levels by inhibiting the activity of $\beta$ hydroxy- $\beta$ methyl glutamyl CoA (HMG-CoA) reductase enzyme which is in cholesterol synthesis. Inhibiting the incorporation of acetate into blood cholesterol by propionic acid competing with acetic acid transporters to hepatocyte cells. This will result in decreased cholesterol synthesis because acetate is a precursor in cholesterol formation. ${ }^{26,27}$

$\mathrm{LAB}$ can assimilate with cholesterol molecules by absorbing cholesterol into the cell membrane. This can reduce the absorption of cholesterol from intestines to blood. ${ }^{28}$ Besides, LAB can inhibit cholesterol through the mechanism of the enzyme coprostanol (a steroid produced by lower intestinal bacteria). LAB convert cholesterol into coprostanol compounds that are not absorbed by the small intestine, this is due to the presence of the enzyme cholesterol reductase produced by LAB. ${ }^{29}$

On the 28th day, the highest decrease at T-4 was by giving dry probiotics a combination of fermented cow's milk and fermented soymilk. In addition to the decline due to LAB, T-4 also contained aglycones from soybean fermentation. Isoflavones containing phytosterols can compete and replace cholesterol in the micelle. The cholesterol-binding phytosterol enters the intestinal lumen by the ABCG5 enzyme transporter that released through the feces. ${ }^{30}$ The fermentation process converts isoflavones into aglycones which are more easily absorbed. Aglycone can inhibit the 3-hydroxy-3-methyl glutaric CoA (HMG CoA) enzymes activity which plays a role in cholesterol synthesis and Acyl-CoA Cholesteryl Acyltransferase (ACAT) enzymes which effect in decreasing cholesterol esterification in the intestine and liver. Aglycone in genistein and daidzein soybean can increase bile acid excretion and regulate LDL receptor activity. ${ }^{31}$

In the study of Adriani et $\mathrm{al}^{32}$, the use of liquid probiotics combined cow's milk and fermented soybean milk with ratio 1: 1 from $1.25 \%$ body weight of broiler chickens can reduce blood cholesterol compared to without probiotic supplementation. Liquid probiotics with a combination of cow and soy milk fermentation can increase HDL and reduce LDL. Probiotics with a combination of fermented cow's milk and soybeans (1: 1) as much as $1,25 \%$ of body weight of broiler chickens can increase HDL until $35 \%$ and significantly decrease LDL until $5875 \%$ compared to without probiotics. ${ }^{24}$ 
RASĀYAN J. Chem.

Vol. 13 | No. 3 |1719-1726| July - September | 2020

Freeze-dried low-fat yogurt with starter Streptococcus thermophilus 1275 and Lactobacillus delbrueckii ssp. bulgaricus 1368 can reduce LDL levels up to $35 \%$ and total cholesterol up to $26,2 \%$. whereas freezedried probiotic yogurt with starter (Streptococcus thermophilus 1275 and Lactobacillus delbrueckii ssp. bulgaricus 1368) and probiotics (Lactobacillus acidophilus 4461, Lactobacillus casei 15286, and Bifidobacteriu llongum 5022) each $1 \%$, can reduce LDL to $1 \% 30 \%$ and total cholesterol up to $26.2 \% .{ }^{33}$

\section{CONCLUSION}

The utilization of oven-dry method was showed a good result for dried probiotics physical quality, however reduce the total of bacteria especially lactic acid bacteria. The administration of dried probiotics reduced blood cholesterol levels in broiler chickens. Administration dried probiotics with only fermented cow's milk (T-2) and a combination of fermented cow's milk and fermented soybean milk (T-4) showed the lowest in blood cholesterol levels compared to other treatments.

\section{ACKNOWLEDGMENT}

The author would be thankful to Applied Research Proposal Program from the Ministry of Research, Technology and Higher Education of the Republic of Indonesia because it has funded this research.

\section{REFERENCES}

1. C. Hill, F. Guarner, G. Reid, G.R. Gibson, D.J. Merenstein, B. Pot, L. Morelli, R.B. Canani, H.J. Flint, S. Salminen, P.C Calder, and M. Sanders, Nature Reviews Gastroenterology and Hepatology, 11, 8 (2014), DOI: 10.1038/nrgastro.2014.66

2. M. Gleeson, N.C Bishop, M. Oliveira, T. McCauley, P. Tauler, and C. Lawrence, International Journal of Sport Nutrition and Exercise Metabolism, 22, 4 (2012), DOI:10.1123/ijsnem.22.4.235

3. L. Adriani, Probiotic bacteria as a starter and the implications of effects on the quality of yogurt, digestive tract ecosystems and the biochemistry of blood of mice, Dissertation, Department of Animal Nutrition and Feed Technology, Padjadjaran University, Indonesia (2005).

4. L. Adriani, 2010, Yoghurt as Probiotic, in: Soeharsono, L. Adriani, O. Sjofjan, S. Ratu, A. Sjamaludin, R. Rita, Lengkey, and A. Mushawwir, Scientific Basis, Applications and Practical Aspects, Widya Karya, Indonesia, pp. 175-196.

5. Y. Cahyati, D.R. Santoso, and U.P. Juswono, Natural B., 2, 2 (2013), DOI:10.21776/ub.naturalb.2013.002.02.2

6. M. Fukuda, M. Kobayashi, and Y. Honda, 2017, Functional Components and Health Benefits of Fermented Soymilk, in: A.M. Grumezescu and A.M. Holban, Soft Chemistry and Food Fermentation, Elsevier Inc., pp.145-178, DOI:10.1016/b978-0-12-811412-4.00006-0

7. A. Masykur and J. Kusnadi, Journal of Food and Agroindustry, 3, 3 (2015).

8. S. Seveline, Journal Agroindustri Halal, 3, 1(2018), DOI:10.30997/jah.v3i1.692

9. T.A. Larkin, L.B. Astheimer, and W.E. Price, European Journal of Clinical Nutrition, 63, 2(2009), DOI:10.1038/sj.ejen. 1602910

10. Evita, Indonesian Journal of Agronomy, 13, 2 (2009).

11. D. Tang, Y. Dong, H. Ren, L. Li, and C. He, Chemistry Central Journal, 8, 1(2014), DOI: $10.1186 / 1752-153 X-8-4$

12. S. Burssens, I. Pertry, D. Diasolua, Y.H. Kuo, M. Van, and F. Lambei, 2011, Soya, Human Nutrition and Health, in: Hany El-Shem, Soybean and Nutrition, inTech, DOI:10.5772/21951

13. L. Adriani, I.M. Joni, C. Kumalasari, and R. Lesmana, Proceeding of $2^{\text {nd }}$ International Conference and Exhibition on Powder Technology (ICEPTI) AIP Conference Proceeding, Surakarta, Indonesia, pp. 15 (2020), DOI: 10.1063/5.0003199

14. K. Hofvendal, and B. Hahn-Hägerdal, Enzyme and Microbial Technology, 26, 2(2000), DOI:10.1016/S0141-0229(99)00155-6

15. NP. Shah, Food Technology, 55, 11(2000).

16. S. Jayanti, Bintari, and Iswari, 2015. Unnes Journal of Life Science, 4, 2(2015).

17. M. Djali, R. Indiarto, and V. Avila, Indonesian Journal of Food Research, 2, 1(2017). 
RASĀYAN J. Chem.

Vol. 13 | No. 3 |1719-1726| July - September | 2020

18. M. Djali, H. Marta, and S. Harnah, Journal Penelitian Pascapanen Pertanian, 13, 1(2016), DOI:10.21082/jpasca.v13n1.2016.28-35

19. B. Koc, M. Yilmazer, P. Balkir, and F. Ertekin, Drying Technology, 28, 4(2010), DOI:10.1080/07373931003613809

20. B.K. Mital, K.H. Steinkraust, and H.B. Neylor, Journal Food Science, 39, 5 (1974), DOI: $10.1111 / j .1365-2621.1974 . t b 07300 . x$

21. J.R. Bordignon, K. Nakahara, T. Yoshihashi, and S. Nikkuni, Japan Agricultural Research Quarterly: $J A R Q$, 38, 4 (2004), DOI:10.6090/jarq.38.259

22. D. Seth, H.N. Mishra, and S.C. Deka, Journal of Food Process Engineering, 40, 3(2017), DOI:10.1111/jfpe.12487

23. C.S. Ranadheera, C.S., C.A. Evans, M.C. Adams, and S.K. Baines, Small Ruminant Research, 123, 1 (2015), DOI: 10.1016/j.smallrumres.2014.10.012

24. L. Adriani, Y. Fransiska, D. Latipudin, and H. Supratman, Scientific Papers. Series D. Animal Science, 60, (2017).

25. A.W. Lengkey and L. Adriani, International Seminar Biotechnology, (2011).

26. N. Kaur and A.K. Gupta, Journal of Biosciences, 27,7 (2002), DOI:10.1007/BF02708379

27. M. Beylot, British Journal of Nutrition, 93, (2001), DOI:10.1079/bjn20041339

28. J.W. Anderson and S.E. Gilliland, Journal of the American College of Nutrition, 18, 1(1999), DOI:10.1080/07315724.1999.10718826

29. A. Baroutkoub, R.Z. Mehdi, R. Beglarian, J. Hassab, S. Zahra, M.S. Mohammad, and E. Hadi, Scientific Research and Essays, 5, 16 (2010).

30. K.M. Robert, Dary, and Victor, 2015, Harper's Biochemistry. 27th Edn., McGraw-Hill,New York, USA.

31. R. Hardaningsih and N. Novik, Biodiversitas, Journal of Biological Diversity, 7, 2(2006), DOI:10.13057/biodiv/d070207

32. L. Adriani, A. Andiany, D. Latipudin, T. Benito, and C. Cahyani, International Journal of Poultry Science, 17, 12(2018), DOI:10.3923/ijps.2018.600.604

33. L. Ramchandran and N.P. Shah, Journal of Food Science,76, 4(2011), DOI:10.1111/j.17503841.2011.02127.x

[RJC-5764/2020] 